DOI No: http://dx.doi.org/10.29228/Joh43490

\author{
Makale Türü: Derleme makalesi \\ Geliş Tarihi: 11.05.2020 \\ Kabul Tarihi: 16.06.2020 \\ On-line Yayın: 25.06.2020
}

Article Type: Review article

Submitted: 11.05 .2020

Accepted: 16.06 .2020

Published Online: 25.06.2020

Atıf Bilgisi / Reference Information

Yıldız, A. (2020). Yeni Gerçekler Işığında Pazarlamanın Holistik Dönüşümü. Journal of History School, 46, 1992-2006.

\title{
YENİ GERÇEKLER IŞIĞINDA PAZARLAMANIN HOLISTTIK DÖNÜŞÜMÜ
}

\section{$\ddot{\mathbf{O} z}$}

\section{Arif YILDIZ ${ }^{1}$}

Teknolojinin geliştiği, küreselleşmenin yayıldığ 1 ve işletmelerin sosyal sorumluluklarının arttığı günümüz dünyasında, müşteri istek, ihtiyaç ve beklentilerinde de büyük değişmeler yaşanmaktadır. Yeni müşterilerin tatmin edilebilmesi ve beklentileri doğrultusunda değerler sunulabilmesi için işletmelerin de bir takım yeni yeteneklere sahip olması gerekmektedir. $\mathrm{Bu}$ çalışmada, etkin pazarlama stratejileri ve programlarının oluşturulmasında büyük öneme sahip olan holistik pazarlama konusu ayrıntılı olarak incelenmiştir. Holistik pazarlama anlayışı; ilişki pazarlaması, bütünleşik pazarlama, içsel ve pazarlama ve perfromans pazarlamasını kapsayan bütünsel bir pazarlama anlayışıdır. "Pazarlama, sadece pazarlamacılara bırakılacak kadar önemsiz değildir" sözü kapsamında pazarlama faaliyetleri ile bir bütün olarak işletmenin tüm bölümleri ve çalışanlarının ilgilenmesi gerekmektedir. İşletmenin beklenen amaçlara ulaşması, birbirleriyle uyumlu bir şekilde hareket eden farklı departmanların özverili çabaları ve her bir çalışanın işletmeyi benimsemesi sayesinde mümkün olabilecektir. Bu kapsamda öncelikle mevcut literatür ve yazın taraması doğrultusunda holistik pazarlama ile ilgili gerekli bilgiler elde edilmiş ve sentezlenmiştir. Sonrasında ise yeni gerçekler 1şığında pazarlama yöneticilerinin izlemesi gereken adımlara dair açıklamalarda bulunulmuştur. Özellikle ulusal anlamdaki literatürde, holistik pazarlama ile ilgili akademik çalışmalar yok denecek kadar azdır. Bu nedenle bu çalışma; pazarlamacılar, akademisyenler, yöneticiler ve ilgili diğer kişiler için bir kaynak niteliği taşıyabilecektir.

Anahtar Kelimeler: Holistik, Holistik Pazarlama, Yeni Gerçekler, Günümüz Pazarlamas1.

${ }^{1}$ Dr. Öğr. Üyesi, Adıyaman Üniversitesi, Gölbaşı Meslek Yüksekokulu, İşletme Yönetimi Program1, arifyildiz@ adiyaman.edu.tr, Orcid: 0000-0002-5149-0447 
Yeni Gerçekler Işığında Pazarlamanın Holistik Dönüşümü

\title{
Holistic Transformation of Marketing in the Light of New Facts
}

\begin{abstract}
In today's world, where technology is developing, globalization is spreading and the social responsibilities of businesses are increasing, there are great changes in customer demands, needs and expectations. In order to satisfy new customers and present values in line with their expectations, businesses must also have a number of new talents. In this study, the subject of holistic marketing, which is of great importance in the creation of effective marketing strategies and programs, is examined in detail. Holistic marketing understanding; is a holistic marketing approach that includes relationship marketing, integrated marketing, internal and marketing, and performance marketing. Within the scope of the statement "Marketing is not insignificant to be left only to marketers", all departments and employees of the business as a whole should be interested in marketing activities. Achieving the expected goals of the business will be possible thanks to the devoted efforts of different departments that act in harmony with each other and the adoption of each business. In this context, firstly, necessary information about holistic marketing was obtained and synthesized in line with the current literature and literature review. Then, in the light of new facts, explanations were made regarding the steps that marketing managers should follow. Academic studies on holistic marketing are almost nonexistent, especially in the national literature. Therefore, this study; it can serve as a resource for marketers, academics, executives and others.
\end{abstract}

Keywords: Holistic, Holistic Marketing, New Facts, Today's Marketing.

\section{GíRiş}

Pazarlama çok çeşitli yaklaşımları içerisinde barındıran bir alandır. On farklı pazarlamacıya "sizce en iyi pazarlama yaklaşımı hangisidir?" şeklinde bir soru yöneltilse belki de 10 farklı cevap alınacaktır. Pazarlama anlayışında yaşanan köklü değişimler ve gelişmeler sşı̆̆ında günümüzde, en iyi ve en etkin pazarlama yaklaşımının bütünsel (holistik) bir bakış açısıyla yaklaşmak olduğu söylenebilir. Holistik pazarlama kavramı, pazarlamaya sadece işin münferit bir bölümü olarak bakmamakta, işin her yönüyle entegre edilmesi gereken bir unsuru olarak bakmaktadır. Bir işletmenin günümüz yeni dünyasında başarılı ve kârlı kalmasının tek yolu budur (Luenendonk, 2019). Bütünsel pazarlama, işletme organizasyonlarının şu anda uygulamak zorunda olduğu modern kavram ve yöntemlerden biri olarak kabul edilmektedir. Çünkü bazı çalışmalar bu kavramın uygulanmasının, müşteri için değer yaratarak ve karlılığı artırarak işletmelerin performansını iyileştirebileceğini göstermiştir (Soliman, 2016, s. 42).

$\mathrm{Bu}$ çalışmada holistik pazarlama anlayışına nasıl gelindiğini göstermek amacıyla öncelikle pazarlama anlayışında yaşanan gelişmeler açıklanacaktır. 
Ardından holistik pazarlama kavramı ve gelişimi açıklanacaktır. Sonrasında yeni gerçekler 1şığında pazarlama yönetiminin görevleri açıklanacak ve son olarak çalışma ile ilgili genel değerlendirmelerde bulunularak sonraki çalışmalar için birtakım önerilerde bulunulacaktır.

\section{PAZARLAMA ANLAYIŞINDA YAŞANAN GELIŞMELER VE YENI PAZARLAMA KONSEPTII}

Günümüz yeni pazarlama gerçekleri göz önüne alındığında, bir işletmenin pazarlama çabalarını hangi felsefeye göre yönlendirmesi gerektiği önemli bir konudur. Bu konunun daha iyi kavranabilmesi için pazarlama anlayışında yaşanan gelişmeleri açıklamak faydalı olacaktır. Pazarlama anlayışında yaşanan gelişmelerin arkasında yatan itici güçler; üretim teknolojisi, rekabet ve tüketici davranışlarında yaşanan değişmelerdir (İslamoğlu, 2013, s. 9).

\section{Üretim Anlayışı ve Pazarlama Konsepti:}

Üretim döneminin yaygın olarak 1870 ile 1930 arasındaki dönemi kapsadığı ifade edilmektedir. Bu dönemin en belirgin özellikler şu şekilde siralanabilir (Fullerton, 1988, s. 108):

$\checkmark \quad$ Firmalar dikkatlerini büyük ölçüde fiziksel üretime odaklamıştır. Tedarik ve üretim engellerinin üstesinden gelebilmek için yeni teknolojiler ve daha verimli yönetim teknikleri kullanılmaktadır.

$\checkmark$ Ürünlerin dağıtımı bağımsız toptancılara ve perakendecilere bırakılmıştır.

$\checkmark$ Üretim anlayışı ve tasarımı, sadece sınırlı ürün gruplarında müşteri ihtiyaç ve gereksinimlerine yönelik olmaktadır. Müşteri ihtiyaçlarına ilişkin düşünce önemli değildir. Çünkü talep, arzı aşmıştır. Herhangi bir ürün için harcanabilir gelir ve istek, geniş nüfus arasında duraklamadan hızla büyümektedir.

$\checkmark$ Her ürün pazarında çok az rekabet vardır; dolayısıyla, toptancılar ve perakendeciler, ürünler zaten "kendilerini sattı̆̆ı" için karmaşık yöntemler geliştirmek zorunda değillerdir.

$\checkmark$ Üretim anlayışı, iş dünyasındaki en eski anlayışlardan biridir.

$\checkmark$ Tüketicilerin yaygın olarak bulunan ve ucuz ürünleri tercih ettikleri iddia edilmektedir.

$\checkmark$ Üretime yönelik işletmelerin yöneticileri, yüksek üretim verimliliği, düşük maliyetler ve toplu dağıtımı elde etmeye odaklanmışlardır.

\section{Ürün Anlayışı ve Pazarlama Konsepti:}


Ürün anlayışının altında yatan temel unsur, üretilmiş olan ürünlerin daha iyisini üretmektir. Bu nedenle ürün anlayışında her zaman tüketicilerin, yenilik içeren, daha kaliteli ve daha çok özelliği olan ürünleri tercih edecekleri varsayılmaktadır. Dolayısıyla bu anlayıştaki işletmeler, sürekli ürün geliştirme üzerinde çalışmaktadır (Aksoy, 2013, s. 33).

Ürün konsepti, tüketicilerin en yüksek kalite, performans veya yenilikçi özellikleri sunan ürünleri tercih edeceklerini ifade etmektedir. Bununla birlikte, yöneticiler bazen ürünleri ile bir aşk ilişkisine yakalanabilirler. Bunun anlamı "daha iyi fare kapanı" yanılgısı nedeniyle, iyi bir ürünün tek başına insanları yönlendirebileceğine inanmaktır. Oysaki yeni veya iyileştirilmiş bir ürün, uygun şekilde fiyatlandırılmadığı, dağıtılmadığı, tanıtımının yapılmadığı ve satılmadığ 1 sürece başarılı olmayacaktır (Kotler \& Keller, 2016, s. 34). Pazarlamacıların "kaliteli ürün üret, nasıl olsa satar" anlayışına sahip olduğu aşamadır (Tekin, 2014, s. 20).

\section{Satış Anlayışı ve Pazarlama Konsepti}

1920-1950 yılları arasında hüküm süren ve odak noktasında mamulün yer aldığı, klasik pazarlama anlayışı olarak da adlandırılan bir anlayıştır (Korkmaz vd., 2009, s. 258). Mevcut malları ne yapıp edip satma ve kâr etme esasına dayandığı için, yoğun satış arttırıcı çabaların, aldatıc1/yanıltıcı reklamların başvurulduğu bir anlayıştır (Mucuk, 2006, s. 120). Satış konsepti, tüketicilerin ve işletmelerin yalnız bırakılmaları halinde bir kuruluşun ürünlerini yeterince satın almayacaklarını iddia etmektedir. En agresif olarak, aranan mallarda -sigorta ve mezarlık arazileri gibi normalde müşterin satın almayı düşünmediği ürünlerfirmaların, pazarın istediklerini yapmak yerine yaptıkları ürünü satmayı hedeflediklerinde uygulanır. Oysaki sert satışa dayalı pazarlama risklidir. Bir ürünü satın alan müşterilerin ürünü iade etmeyecekleri, kötü niyetli olmayacakları veya tüketici kuruluşlarına şikayette bulunmayacakları, hatta tekrar satın alabilecekleri varsayımlarına dayanır (Kotler \& Keller, 2016, s. 34).

\section{Pazarlama Anlayışı ve Pazarlama Konsepti:}

Mevcut malı her ne pahasına olursa olsun, yanıltıcı reklamlara başvurarak da olsa satmanın uzun vadede sağlıklı bir işletme-tüketici ilişkisine olanak vermediğinin zamanla anlaşılmasılya, kısaca tüketiciyi tatmin ederek kar sağlama şeklinde ifade edilen bir pazarlama anlayışı doğmuştur (Mucuk, 2010, s. 9). Pazarlama konsepti 1950'lerin ortalarında müşteri odaklı bir anlayışla ortaya çıkmıştır. Ürünleriniz için doğru müşterileri değil, müşterileriniz için doğru ürünleri bulmak felsefesine dayanır. Pazarlama konsepti, kurumsal hedeflere ulaşmanın anahtarını, hedef pazarlarda üstün müşteri değeri yaratma, sunma ve 
iletme konusunda rakiplerinden daha etkili olmak şeklinde ifade etmektedir. Çünkü satış ve pazarlama anlayışı birbirinden farklıdır. Satış, satıcının ihtiyaçlarına odaklanırken; pazarlama, alıcının ihtiyaçlarına odaklanır. Satış, satıcının ürününü nakde dönüştürme ile meşgul olurken; pazarlama, ürün ve müşteri yaratma, ürünü müşteriye sunma ve nihayetinde tüketme ile ilgili şeylerin bütünü aracılığıyla müşterinin ihtiyaçlarını karşılama anlayışına sahiptir (Kotler \& Keller, 2016, s. 34). Nitekim günümüzde üretilen her ürün veya hizmetin satılma garantisi bulunmamaktadır. İnsanların mevcut veya gelecekte ortaya çıkabilecek ihtiyaçlarını en üst düzeyde karşılayacak ve bunu en uygun koşullarda (fayda, kolaylık, maliyet, doğru bilgi) sağlayacak olan işletmeler rekabet üstünlüğü elde edebileceklerdir (Ertan, 2016, s. 220). Geçmişteki "satılan mal geri alınmaz" düşüncesi yerini "koşulsuz müşteri memnuniyeti" anlayışına bırakmıştır. $\mathrm{Bu}$ anlayış beraberinde değer kavramını ön plana çıkarmıştır. "Müşteriyi mutlu ederek mutlu olmak" yani "vererek almak" günümüzün en önemli pazarlama anlayışını ifade etmektedir (Tek, 2006, s. 328).

\section{HOLISTIKK PAZARLAMA KAVRAMI VE GELISSIMI}

Holistik pazarlama kavramı, ürünleri, çalışanları, rakipleri ve hatta çevreyi kapsayan, pazarlamanın tüm yönlerinin çok önemli olduğunu bilir. Bu nedenle geniş ve daha entegre olmuş bir bakış açısı gerektirir. Kotler ve Keller'e (2009) göre holistik pazarlama; sadece bir şirketi değil, bir şirketin varlığını bir bütün olarak tanımlayan pazarlama kavramdır. Şirketin holistik pazarlamada bir bütün olarak tanımlanması, şirketi diğer çeşitli unsurlarla entegre olan bir bütün olarak görmek demektir. $\mathrm{Bu}$ unsurlar; işletmenin müşterilerini (tüketicilerini), paydaşları ve tedarikçileri içermektedir. Bu bağlamda işletmeler, tüketicileri "bir işletmenin gelişimindeki en önemli parça” olarak görmelidirler. Çünkü tüketiciler, işletme başarısında büyük bir paya sahiptir. Üstelik ağızdan ağıza iletişim kurmaları da mümkündür (Kim ve ark. 2009; akt: Sulivyo vd., 2019, s. 187-188).

Holistik pazarlama; ihtiyaçları tanımak, istek ve talepleri karşılamak ve müşterilere benzersiz bir değeri önerisi sunmak şeklindeki tüm pazarlama işlevlerini mantıklı bir süreçte birleştiren bir stratejidir. Holistik pazarlama kavramı, pazarlama programlarının, süreçlerinin ve faaliyetlerinin genişlik ve karşılıklı bağımlılık ile planlanması ve uygulanmasına dayanır. Holistik pazarlama yaklaşımını kullanan işletmeler, işletmeyi bir bütün olarak düşünerek pazarlama stratejisi geliştirirler. $\mathrm{Bu}$, işletmenin her yönünün dikkatle değerlendirilmesi gerektiği anlamına gelir. Şirket, bir tüketicinin o şirkete ait 
ürünleri, reklam malzemeleri ve diğer tüm unsurlarla nasıl etkileşime gireceğini düşünmek zorundadır (Tushi, 2014, s. 12-13).

\section{HOLISTIK PAZARLAMANIN BOYUTLARI}

Holistik pazarlama, pazarlamada her şeyin önemli olduğunu ve genellikle geniş ve bütünleşmiş bir bakış açısının gerekli olduğunu kabul eder. Böylece holistik pazarlama, pazarlama faaliyetlerinin kapsamını ve karmaşıklıklarını tanır ve uzlaştırır. Şekil 1. Holistik pazarlamayı karakterize eden dört geniş bileşenin şematik bir genel görünümünü sunmaktadır (Kotler \& Keller, 2016, s. 35):

Şekil 1. Holistik Pazarlamanın Boyutları

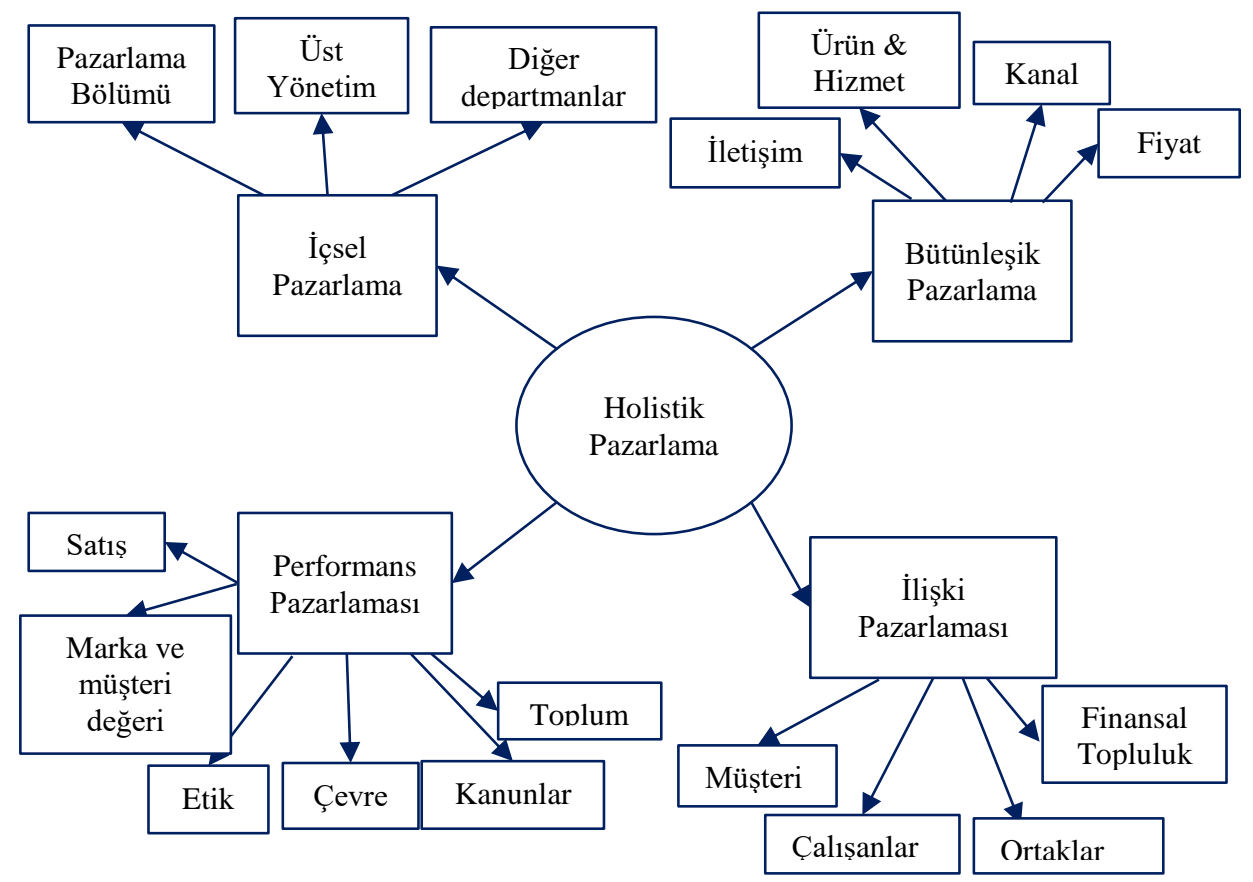

Kaynak: Kotler \& Keller (2016, s. 35)

\section{İçsel pazarlama}

İçsel pazarlama, bir işletmenin dış pazardaki performansını iyileştirmenin yolu olarak, kendi çalışanlarıyla (iç pazar) ve ortaklarıly (ara pazar) etkileşim kurması anlamına gelmektedir (Dunmore, 2002, s. 5). Çalışanlar arasında uyumlu ve olumlu anlamda ilişkilerin geliştirilmesi, bilinçli bir şekilde yapılan iş bölümü, 
iş birliğinin sağlanması ve özellikle işletmede sosyal bütünlüğün gerçekleşmesi, üretim ve verimlilik artışlarını beraberinde getirecektir (Sabuncuoğlu \& Tokol, 2013, s. 25).

Ayrıca içsel pazarlama faaliyetleri ile kurumsal itibar arasında pozitif yönde anlamlı bir ilişkinin olduğu söylenebilir. Bu nedenle hem firma başarısı hem de müşteri memnuniyeti çısından firma çalışanlarına gereken önemin verilmesi gerekmektedir (Fettahlığlu vd. 2016, s. 42).

Holistik pazarlamanın bir unsuru olan içsel pazarlama, müşterilere iyi hizmet vermek isteyen yetenekli çalışanları işe alma, eğitme ve motive etme görevidir. Akıllı pazarlamacılar, firma içindeki pazarlama faaliyetlerinin şirket dışına yönelik faaliyetler kadar önemli veya hatta onlardan daha önemli olabileceğini kabul ederler (Kotler \& Keller, 2016, s. 36). Literatür taramasında daha çok içsel pazarlama faaliyetlerinin tanımlamalarına odaklanıldığı, uygulama sürecine çok fazla değinilmediği görülmektedir. Cătălin vd. (2014, s. 11), içsel pazarlama uygulama modelinin Şekil 2'deki gibi olabileceğini ifade etmiştir.

Şekil 2. İçsel Pazarlama Uygulama Modeli

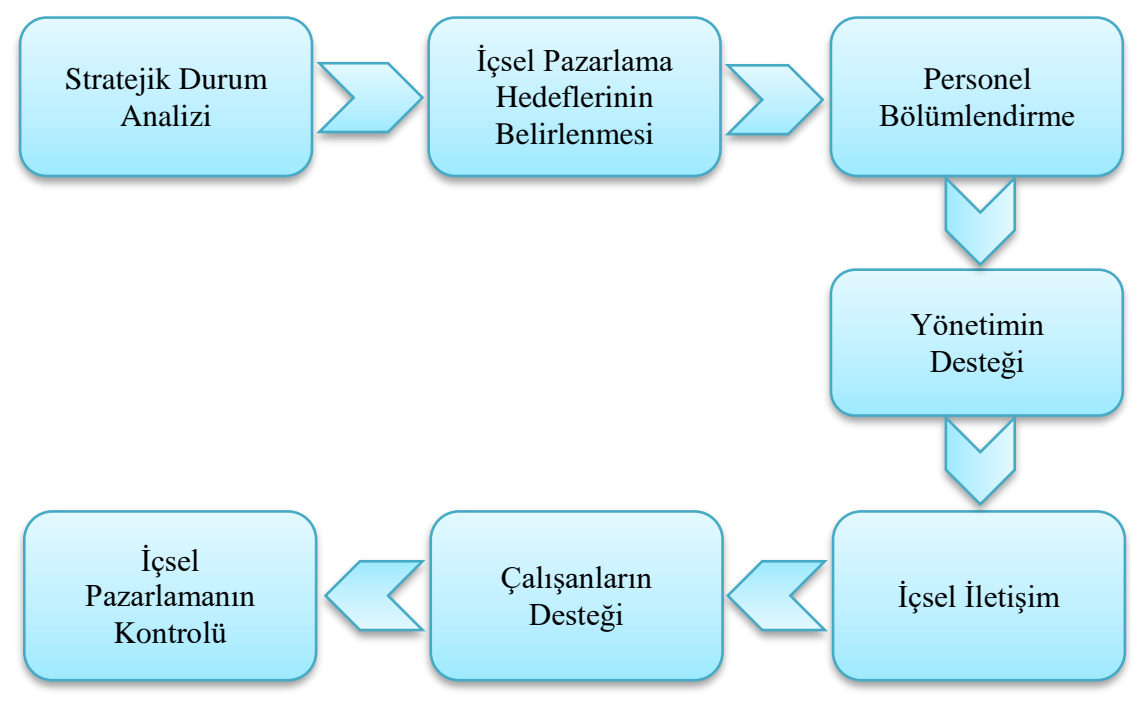

Kaynak: (Cătălin, Andreea, \& Adina, 2014, s. 11)

Şekil 2'deki model incelendiğinde içsel pazarlama uygulamasının stratejik durum analizinden başlayarak içsel pazarlama kontrolüne kadar uzanan 7 farklı aşamaya ayrıldığı görülmektedir: 
İçsel pazarlama uygulamasının başlangıç noktası, işletmenin mevcut durum analizinin yapılmasıdır. $\mathrm{Bu}$ analiz dört ana alanda işletmenin güçlü ve zayıf yönlerini belirlemeye odaklanacaktır. Bunlar; çalışanların müşterilere yönelimi, şirketin personele yönelimi, örgüt kültürü ve liderlik tarzı şeklinde sıralanabilir. Çalışanların müşterilere yönelimi ve şirketin personele yönelimi, içsel pazarlama uygulamalarının bir göstergesidir (Cătălin vd., 2014, s. 11). Çalışanların müş̧erilere, şirket yönetiminin ise çalışanlara ne derece ilgi gösterdiği içsel pazarlama kalitesinin ne düzeyde olduğunu gösterecektir.

Stratejik durum analizinden sonraki ikinci aşama, içsel pazarlama hedeflerinin belirlenmesidir. Belirlenecek bu hedefler, işletmenin genel amaçlarına ulaşmak için, motive olmuş, müşterilerin ihtiyacını karşılamaya hazır personellerin geliştirilmesine yönelik olmalıdır.

Üçüncü aşama çalışanların bazı kriterlere göre bölümlendirilmesidir. Bölümlendirme kriterleri; yaş, cinsiyet gibi demografik kriterler olabileceği gibi, işletmeye bağll1ık düzeyi, o işletmedeki tecrübe süresi gibi başka kriterler şeklinde de olabilir. Çalışanların bu şekilde bölümlere ayrılmış olması, her bir çalışana özel motivasyon veya eğitim-geliştirme faaliyetlerinin uygulanmasına olanak sağlayacaktır.

İçsel pazarlama uygulamasının dördüncü aşaması yönetimin desteğidir. Bir organizasyondaki önemli yönetimsel değişiklikler hiyerarşinin en üst basamağından başlar ve gittikçe aşağı doğru kademeli olarak yayılır. İçsel pazarlamanın bir kuruluşta başarılı bir şekilde uygulanması, tüm uygulama aşamalarında yönetimin vereceği desteğe ve içsel pazarlama faaliyetlerine yönetimin katılma düzeyine bağlıdır (Cătălin vd., 2014, s. 13).

Beşinci aşama içsel iletişim aşamasıdır. Örgüt içerisinde yatay (aynı seviyedeki çalışanlar arasında), dikey (yukarıdan aşağıya veya aşağıdan yukarıya) ya da çapraz (farklı birimlerdeki çalışanlar arasında) iletişimin kalitesi içsel pazarlama uygulamasının en önemli aşamalarından biridir.

İçsel pazarlama uygulamasının altıncı aşaması çalışanların desteği aşamasıdır. Çalışanların katılımı, çalışanların şirkete ve şirket faaliyetlerine olan bağlılığını artıran, ekip olarak çalışma arzusunu teşvik eden tedbirlerin bir kombinasyonudur. Sürecin verimli olması için, çalışanların katılımı, işveren ve çalışan arasındaki çift yönlü iş birliği ve karşılıklı destek ilişkileri üzerinde dikkatlice durulmalıdır. Daha yüksek düzeyde katılımın çalışanlar üzerinde; örgütün bir parçası olmak için daha güçlü bir istek, gerektiğinde ek çaba içerisinde bulunma ve olumlu mesajlar verme gibi faydaları olacaktır (Cătălin, Andreea, \& Adina, 2014, s. 14). 
İcsel pazarlamanın yedinci ve son aşaması içsel pazarlamanın kontrolü aşamasıdır. $\mathrm{Bu}$ aşamada içsel pazarlama uygulamalarının istenen amaç doğrultusunda ilerleyip ilerlemediğinin kontrolü yapılmaktadır.

\section{Bütünleşik Pazarlama}

Bütünleşik pazarlama anlayışına göre; tüketicilere yönelik olarak "bütün, kendisini oluşturan parçaların toplamından daha büyüktür" şeklinde bir değer yaratmak, iletişim kurmak ve sunmak için birtakım etkinlikler ve programlar tasarlandığında, pazarlama faaliyeti gerçekleşecektir. Bütünleşik pazarlama yaklaşımının İki önemli teması şunlardır (Kotler \& Keller, 2016, s. 36):

1. Birçok farklı pazarlama faaliyeti tüketiciler için değer yaratabilir, onlarla iletişim kurabilir ve onlara değer katabilir.

2. Pazarlamacılar her bir pazarlama faaliyetini, diğer tüm pazarlama faaliyetlerini göz önünde bulundurarak tasarlamalı ve uygulamalıdır.

Örneğin bir işletme, faaliyetlerinde kullanmak üzere büyük bir makine satın aldığında, o makinenin kurulumu, bakım-onarımı ve nasıl kullanılacağına dair eğitim verilmesi gibi hizmetlere de devam edilmesini ister.

Bütünleşik pazarlama faaliyetleri; rekabet üstünlüğü elde edebilmek, hedef kitleyi bilgilendirmek, onlarla sürekli bir iletişim sağlayabilmek için işletmelerin başvurduğu yollardan biridir (Erdoğan Tarakçı \& Baş, 2019, s. 168).

Tüketiciye dönük tutum pazarlama anlayışı açısından ne kadar önemli ise, bütünleşmiş pazarlama anlayışı da o derece önemlidir. Bütünleşik pazarlama anlayışı, bir işletmenin sadece pazarlama bölümünün çabaları ile başarı elde edemeyeceği, işletmenin bir bütün olarak ele alınması gerektiğini savunur. İşletmenin başarılı olması, işletmedeki bütün bölümlerin ortak amaç doğrultusunda faaliyetlerini bütünleştirip yürütmeleri ile elde edilecektir (İslamoğlu, 1999, s. 23).

\section{Performans Pazarlaması}

İşletmelerin kuruluşundaki temel amaç karlılıktır. Fakat bu amacın gerçekleşmesine dönük faaliyetler sırasında gözönünde bulundurulması gereken bazı unsurlar bulunmaktadır. Bu unsurar; etik ilkeler, hukuki kurallar, çevrenin ve toplumun çıkarları şeklinde sıralanabilir (Fettahlığlu \& Yıldız, 2016, s. 262). Performans pazarlaması, pazarlama faaliyetleri ve programları sırasında iş ve topluma finansal ve finansal olmayan getirileri anlamayı gerektirir. Üst düzey 
pazarlamacılar pazar payına, müşteri kayıp oranına, müşteri memnuniyetine, ürün kalitesine ve diğer önlemlere nelerin etki edeceğini tespit etmek amaciyla, sadece satış gelirleri ile ilgilenmezler. Ayrıca pazarlama faaliyetlerinin ve programlarının yasal, etik, sosyal ve çevresel etkilerini göz önünde bulundururlar (Kotler \& Keller, 2016, s. 36).

\section{İlişki Pazarlaması}

Pazarlamanın en temel amaçlarından biri, işletmenin pazarlama faaliyetlerinde doğrudan veya dolaylı etkileyici konumundaki tüm kişi ve kuruluşlarla güçlü ve sürekli ilişkiler geliştirmektir. İşletmenin bu amacına ulaşması için kullanılan yöntem anlamına gelen ilişki pazarlaması, müşterilerle, çalışanlarla, ortaklarla, kanal üyeleriyle ve bir takım finansal çıkar gruplarıyla dengeli ilişkiler geliştirmesine dayanır (Yükselen, 2012, s. 15). İlişki pazarlaması, mevcut müşteriler ile olan ilişkileri geliştirip uzun vadede müşteri sadakati oluşturmakmevcut müşterilerin alımlarını bir yandan sürekli hale getirmek bir yandan da müktar anlamında artış sağlamak için planlanan ve uygulanan bir pazarlama stratejisidir (Kıllç, 2018, s. 259).

İşletmelerin günümüz belirsiz ortamına ayak uydurabilmeleri, daha güçlü ve daha sağlıklı müşteri ilişkileri geliştirmelerine bağlıdır. Müşterileriyle birebir ilgilenmek suretiyle onları özel hissettiren, onların ihtiyaç ve istekleri doğrultusunda düşüncelerine önem veren, bu istek ve ihtiyaçlarını en iyi şekilde karşılayarak, onların tatmin olmalarını sağlayan işletmeler, rekabetçi avantajı kazanacak ve pazardaki yerlerini koruyabilecek veya arttırabilecektir (Yürük \& Kapaypınar, 2016, s. 100).

\section{YENI GERÇEKLER IŞIĞINDA PAZARLAMA YÖNETIMINININ GÖREVLERİ}

Günümüz pazarlama anlayışında temel nokta müşteriyi işletme stratejilerinin odak noktasına koymaktır. Karşınızdakilerin istek ve ihtiyaçlarını, ilgilerini ya da algılama düzeylerini ölçmeden, sadece kendinizi merkeze alıp yine kişisel ilgilerden hareketle anlatılacak her şey, en nihayetinde kendinizi, o da bir süreliğine tatmin etmekten öteye gidemeyecektir (Saydam, 2012, s. 41). Müşteri odaklı çalışmanın etkin bir şekilde yürütülebilmesi bütüncül bir pazarlama anlayışı sayesinde olacaktır. David Packard'ın ifadesi ile "pazarlama, sadece pazarlama birimine bırakılacak kadar önemsiz değildir”. Dünyada en iyi pazarlama birimlerine sahip olan işletmelerin bile başarısız olabileceği görülmektedir. Nitekim imalatçılar düşük kaliteli ürün çıkarabilir, yükleme 
departmanı işleri geciktirebilir ya da muhasebe departmanı hatalı fatura kesebilir. Böylesi bir durumda müşteri kaybı yaşanabilecektir. Pazarlama ancak bütün personelin, müşteriye verilen değer sözünü tutmak ve müşteriyi memnun etmek için çaba göstermesi halinde başarılı olacaktır (Kotler, 2007, s. 14). Özellikle teknolojide yaşanan yenilikler, küreselleşmenin etkisi ve artan sosyal sorumluluk gibi nedenlerle müşteri yeteneklerinde birçok yeniliğin ortaya çıktı̆̆ görülmektedir. Gelişen müşteri yeteneği doğrultusunda müşteri ihtiyaç ve isteklerinin karşılanması, şirketlerin de yeteneklerini geliştirmeleri ile sağlanabilecektir.

Şekil 3, yeni pazarlama gerçeklerini yakalamaya yardımcı olan üç büyük piyasa gücünü, iki temel pazar sonucunu ve holistik pazarlamanın dört temel boyutunu özetlemektedir. İşletmeler bu kavramları etkilim bir şekilde yürütürlerse, başarılı pazarlama yönetimi ve pazarlama liderliğinden söz edilebilecektir. Yeni pazarlama gerçekleri 1şığında üst yönetimin de desteği ile pazarlama yöneticilerinin izlemesi gereken adımlar şu şekilde sıralanabilir (Kotler \& Keller, 2016, s. 38-39):

$\checkmark$ Pazarlama strateji ve planlarının geliştirilmesi ve uygulanması,

$\checkmark$ Pazarlama öngörülerini yakalamak,

$\checkmark$ Müşterilerle bağlantı kurmak,

$\checkmark$ Güçlü markalar oluşturmak,

$\checkmark$ Marka konumlandırması ve etkili bir şekilde rekabetin planlanması,

$\checkmark$ Değer yaratma,

$\checkmark$ Ürün ve hizmetlere dayanarak, hedef pazara değer katmak,

$\checkmark$ Etkili iletişim,

$\checkmark$ Pazarlama organizasyonunu uzun vadeli başarı amacıyla yönetmek.

Şekil 3. Yeni Pazarlama Gerçekleri 


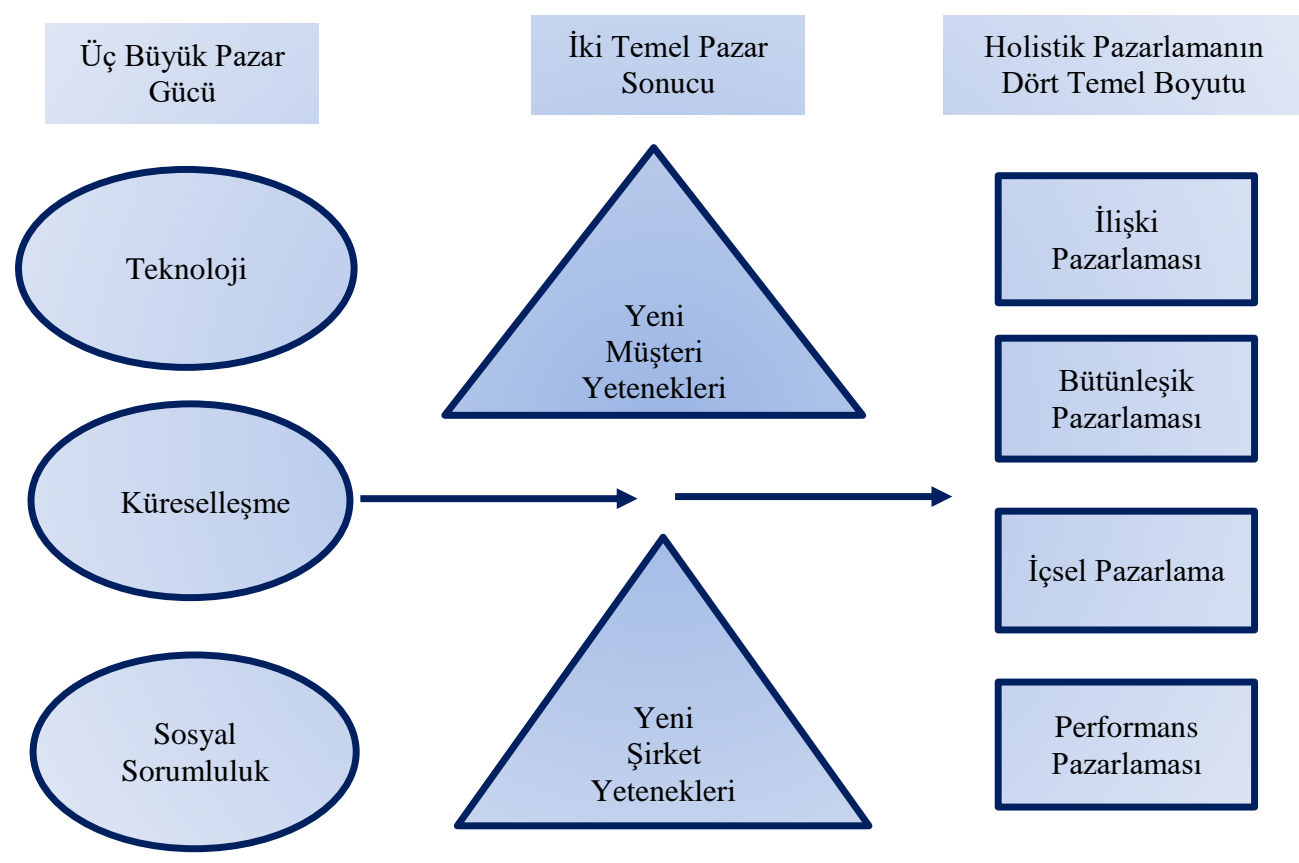

Kaynak: Kotler \& Keller (2016, s. 38)

\section{SONUÇ}

Holistik (bütünsel) pazarlama ile bir işletmenin performans1 arasında önemli bir ilişki bulunmaktadır. Bu nedenle işletmeler, pazar payının kornuması ve arttırlması amacıyla, mevcut müşterileri elde tutmak, yeni müşteriler çekmek, müşteri sadakati oluşturmak, müşteri memnuniyeti sağlamak, yatırım getirisi kazanmak, kârın arttırılması, verimlilik, nakit akışı gibi konular üzerinde durmalidır (Soliman, 2016, s. 54).

Günümüzde yöneticiler ve bilimsel çevrelerinin; müşteri memnuniyeti, gelecek nesiller için uzun vadeli refah ve işletmenin kârı konuları arasında bir uzlaşmanın mümkün olup olmayacağı ya da bunun nasıl mümkün olacağı üzerinde düşünmeleri gerekmektedir (Rudawska, 2017, s. 1). Holistik pazarlama; içsel pazarlama, bütünleşik pazarlama, ilişki pazarlaması ve performans pazarlamasını bünyesinde barındıran çok yönlü bir pazarlama anlayışıdır. İçsel pazarlama anlayışı ile çalışanların memnuniyeti, eğitim ve gelişimleri, işe ve 
örgüte bağlılıkları, örgütü sahiplenmeleri gibi konuları kapsamaktadır. Bütünleşik pazarlama anlayışı, pazarlamanın sadece pazarlama bölümünün değil, işletmenin br bütün olarak tamamının görevi olduğu anlayışına dayanmaktadır. İlişki pazarlaması, işletmenin doğrudan veya dolaylı olarak etkileyici konumundaki tüm kişi ve kuruluşlarla güçlü ve sürekli ilişkiler geliştirmeyi amaçlar. Performans pazarlaması ise bir yandan satış ve müşteri değeri kavramları üzerinde dururken bir yandan da pazarlama programlarının; yasalara, etik kurallara ve çevresel değerlere uygun olmasını amaçlamaktadır.

Bu çalışma, derinlemesine alan yazın incelemesi ve mevcut literatürlerin analizinden yola çıkarak kavramsal çerçeveyi oluşturmak amacıyla hazırlanmıştır. Holistik pazarlama konusunda araştırma yapmak isteyen yönetici, akademisyen ve ilgili diğer araştırmacıların;

- Holistik pazarlamanın örgüt performansı üzerindeki etkisi,

- Holistik pazarlamanın her bir boyutunun pazarlama performans1 üzerindeki etkisi,

- Holistik pazarlamanın farklı sektörlerdeki uygulama düzeylerinin ölçülmesi gibi konular üzerinde de çalışma yapmaları faydalı olabilecektir.

\section{KAYNAKÇA / REFERENCES}

Aksoy, R. (2013). Pazarlama düşüncesinin gelişimi pazar odaklılık ve stratejik düşünme. İ. Kırcova, \& T. Benli (Ed), Pazarlama Yönetimi içinde (s. 1742). Lisans Yayınc1lik.

Cătălin, M., Andreea, P. \& Adina, C. (2014). A Holistic approach on internal marketing implementation. Business Management Dynamics, 3(11), 0917.

Dunmore, M. (2002). Inside-Out Marketing: How to Create an Internal Marketing Strategy. British Library cataloguing in publication data.

Erdoğan Tarakçı, İ. \& Baş, M. (2019). Pazarlama iletişiminde sosyal medya kullanımı: amaçlar ve motivasyonlar. Euroasia Journal of Social Sciences \& Humanities, 7, 167-179.

Ertan, H. (2016). Pazarlama. M. Kara \& H. Ertan (Ed) Genel İsletme içinde (s. 219-246). Lisans Yayıncilik.

Fettahlığlu, H., \& Yıldız, A. (2016). Pazarlama fonksiyonu. İ. Bakan (Ed.) içinde, İ̧sletme Bilimine Giriş (s. 243-291). Beta Basım A.Ş. 
Fettahlıŏglu, H., Fettahlıŏlu, Ö., Yıldız, A. \& Birin, C. (2016). İçsel pazarlamanın kurumsal itibar üzerine etkisi: Bir Alan araştırması. International Journal of Academic Value Studies, 2(3), 30-45.

Fullerton, R. (1988). How modern is modern marketing? Marketing's evolution and the myth of the "production era". Journal of Marketing, 52(1), 108125.

İslamoğlu, A. (1999). Pazarlama Yönetimi (Stratejik ve Global Yaklaşım). Beta Basım A.Ş.

İslamoğlu, A. (2013). Pazarlama İlkeleri (4 b.). Beta Basım A.Ş.

K1lıç, K. (2018). İlişkisel Pazarlama. Y. Akçi (Ed.) içinde, Değişen Pazarlama Anlayışı: Yeni Pazarlama Yaklaşımları (s. 259-290). Gazi kitabevi.

Korkmaz, S., Eser, Z. \& Öztürk, S. (2009). Pazarlama Kavramlar-IllkelerKararlar. Siyasal Kitabevi.

Kotler , P. \& Keller, K. (2016). A Framework for Marketing Management Sixth Edition Global Edition. British Library cataloguing-in-publication data.

Kotler, P. (2007). Soru ve Cevaplarla Günümüzde Pazarlamanın Temelleri. (Ü. Şensoy, Çev.) Optimist yayınları.

Luenendonk, M. (2019, July 7). Holistic Marketing - Meaning, Concepts and Importance. https://www.cleverism.com/holistic-marketing-meaningconcepts-and-importance/, Erişim tarihi: 09.05.2020

Mucuk, İ. (2006). Pazarlama Illkeleri. Türkmen Kitabevi.

Mucuk, İ. (2010). Pazarlama İlkeleri (ve Yönetimi İçin Örnek Olaylar). Türkmen Kitabevi.

Rudawska, E. (2017). Sustainable marketing concept - A New face of capitalism. British Journal of Research, 4(2:10), 1-2.

Sabuncuoğlu, Z. \& Tokol, T. (2013). Meslek Yüksekokullarl için Genel İşletme. Beta Basım A.Ş.

Saydam, A. (2012). Illetişimin Akıl ve Gönül Penceresi: Algılama Yönetimi. Remzi Kitabevi.

Soliman, H. (2016). An Analytical Study of the Relationship between the Holistic Marketing and Overall Organizational Performance. International Journal of Business and Social Science, 7(7), 42-56. 
Sulivyo, L., Siswoko, R., \& Tegor. (2019). The effectiveness of holistic marketing and word-of-mouth communication on purchasing decision at pt asuransi central asia branch office of tiang bendera west Jakarta. International Journal of Multicultural and Multireligious Understanding, 6(1), 187-199.

Tek, Ö. (2006). Pazarlamada Değer Yaratmak. Hayat Yayıncılık.

Tekin, V. (2014). Pazarlama Illkeleri: Politikalar-Stratejiler-Taktikler. Seçkin yayıncılık san. ve tic. A.Ş.

Tushi, T. (2014). Holistic service marketing strategies and corporate objectives of firms. Global Journal of Management and Business Research: E Marketing, 14(1), 6-27.

Yükselen, C. (2012). Pazarlama, Illkeler - Yönetim - Örnek Olaylar. Detay Yayıncilik.

Yürük, P. \& Kapaypınar, Ö. (2016). İlişki pazarlamasi bileşenleri ile imaj ve müşteri sadakati arasindaki ilişkilerin incelenmesine yönelik bir uygulama. Balkan ve Yakın Doğu Sosyal Bilimler Dergisi, 2(2), 100-110. 